\title{
Dynamism of Tax Revenue Potential in Sub-Saharan African Countries: A Truncated-Normal Distributional Analysis
}

\author{
Agumas Alamirew Mebratu (MSc, Ph.D. Fellow in Taxation) \\ BAHIR DAR UNIVERSITY, COLLEGE OF BUSINESS and ECONOMICS DEPARTMENT OF \\ ACCOUNTING AND FINANCE, Ethiopia \\ Fentaw Leykun (Ph.D) \\ BAHIR DAR UNIVERSITY, COLLEGE OF BUSINESS and ECONOMICS DEPARTMENT OF \\ ACCOUNTING AND FINANCE, Ethiopia \\ Merouane Lakehal-Ayat (Professor) \\ BAHIR DAR UNIVERSITY, COLLEGE OF BUSINESS and ECONOMICS, DEPARTMENT OF \\ ACCOUNTING AND FINANCE, Ethiopia
}

\begin{abstract}
Although taxation is the most effective alternative to long-term funding of public spending, sub Saharan African countries typically experience a persistent gap between the amount of actual tax revenue and their potential. The main aim of this paper is to analyze tax revenue potential drivers in sub-Saharan African countries using truncatednormal distributional analysis panel data from 2000 to 2018. Finding the estimate result shows that the potential for tax revenue has a positive significant correlation with GDP per capita, trade openness, agricultural sector, service sector, manufacturing sector, monetization, population growth, urbanization, and government stability. By comparison, a significant negative link to inflation, income inequality (Gini coefficient), construction industry, age dependency, population density, foreign direct investment, official exchange rate, official development assistance, and corruption. In conclusion, this research confirms that both supply and demand-side variables influence the capacity for tax revenues. Hence, in general, this study recommended that before implementing a new tax revenue policy, the concerned body of any country should first determine their tax revenue potential and their determinants accordingly. The results of the study are expected to contribute insights for an empirical model of a comprehensive examination of the determinants of tax revenue potential and its determinants in Sub- Saharan African countries.
\end{abstract}

Keywords: Dynamism, tax revenue potential, Sub- Saharan Africa, truncated-normal distribution, panel data DOI: $10.7176 / \mathrm{JESD} / 11-9-08$

Publication date:May $31^{\text {st }} 2020$

\section{INTRODUCTION}

Taxation is the principal tool for the collection of revenues for each developing and developed economy (Sheikh et al., 2018). Efficient taxation strategies may help improve the revenue of governments, reduce the need for public borrowing, reduce aid dependency, reduce excess dependence on commodity exports and increase countries ' ownership of their development agenda (AEO, 2013). A better tax management and revenue mobilisation can improve the performance of tax revenue and strengthen the relationship between the state, including the private sector and civil society. Governments have relied heavily on foreign assistance and debt financing in sub-Saharan African countries for public goods, such as health, basic education, and infrastructure. Domestic tax revenue may play a major role in financing such expenditure (IMF, 2018).

The collection of tax revenues has it has regarded long as a cornerstone central to every nation's growth and development. Governments are required to spend more on public services to advance development, and this can be achieved by improving the mobilisation of their tax revenue. However, the collection of tax revenue in subSaharan Africa has historically been low, as governments rely heavily on foreign aid and debt financing to finance these vital public goods. For example, the average aid to gross domestic product (GDP) ratio for the region over the period 1990-2018 was 53\%, while tax revenue mobilisation on average was only $15 \%$ of GDP in 1980 to $18.2 \%$ in 2018 (IMF, 2018).

Interest in rising revenue overall performance has received extended momentum in the late years across several growing countries (Drummond et al., 2012 \& AfDB, 2010a). This has been on account of enlarged funding wishes for supplier delivery, issues over debt property, and waning donor guide throughout several countries. Whereas the overall revenue performance has now not been alert to general value growth, it's not clear that explicit sectors of the economic system are responding or not. A clearer understanding of sector-specific tax elasticity's will provide higher policy choices for raising tax revenue performance.

Most previous researchers like (Bird 2010; Martinez-Vazquez, McLure and Vaillancourt, 2006; Ebel and Taliercio, 2005; Olowu \& Wunsch, 2003) agreed that maintaining a good revenue system is an essential 
prerequisite for the success of fiscal decentralisation for most developing and developed countries. Because, maintaining good revenue system besides raising revenues, domestic revenue mobilisation has the power to enhance political and administrative accountability by empowering communities as explained by (Smoke, 2003; Mikesell, 2007, 2002; Shah, 1999; Oates et al., 2000). However, domestic revenue potential by the means of tax in developing countries because of tax collection inefficiency has been often low and collection costs as high as compared with many developed countries.

As stated by the EU (2015), developing countries, especially low- and lower-middle-income economies of Sub - Saharan African countries, face significant challenges in revenue mobilisation. Their tax-to-GDP ratios range from 10 to $20 \%$, as opposed to 25 to $40 \%$ in developed countries. As a result, the first step to an understanding of public revenue systems in an agreement with the prevailing literature is to define and create certain typically agreed performance measurements and benchmarks. The focal point of earlier studies at the low tax collection in lots of developed countries became on the supply-side factors to tax handles such as, without difficulty taxed (the effectively available) economic activities, as an example, foreign trade and mining (see, for instance, Lotz and Morss,1967; Bahl,1971; Leuthold,1991; Tanzi,1992; Stotsky and WoldeMariam,1997; Ghura,1998; Piancastelli,2001; Eltony,2002 \& Gupta,2007), stated within the preliminary technique, which describe the traditional regression approach. It makes the capacity or potential tax revenues from the expected values based on regression evaluation. The conventional approach offers in a hallmark of this is clear however that typically has vital limitations to inform coverage reform. From an explicit as of a point of view, the conventional regression approach does no longer offer a yardstick of expected revenues, however, it generates a notional price of revenue capacity if the number of predicted parameters had been to comply with the identical sample in that country.

Therefore, by having the limitation of the regression approach to predict tax potential in cross-country context, in this research to determine cross country's tax revenue potential, the latest method of stochastic frontier analysis by considering countries' tax revenue potential depends on both supply-side and demand-side factors in 23 Sub Saharan African countries from 2000 to 2018. This approach predicts longer offer a yardstick of expected tax revenue potential. Above all stochastic frontier analysis techniques, which support a more intuitive - and potentially more policy-relevant - the measure of tax potential and then can generate a stochastic tax frontier, which defines an estimated maximum potential tax-to-GDP ratio for a set of determinant inputs and environmental factors. Besides, the extant paper not only examines the tax revenue potential in one sort of view that factors that influence it in a developing country context, but also, there have been few comprehensive empirical examination economic, demographic, policy and institutional factors in Sub- Saharan African countries. Therefore, the main objective of this paper has a look at desires to examine comprehensively economic, demographic, policy and institutional factors for tax revenue potential.

The next section of the study as follows. Section 2 discusses the theoretical and empirical literature in this area. The methodological framework, data/sample and estimation technique are presented in Section 3. The empirical results of the stochastic frontier analysis estimate it presents tax revenue potential in Section 4 and the last section 5 concludes the study.

\section{Literature review and hypothesis development}

In this paper economic, demographic, policy and institutional factors for tax revenue potential are to review comprehensively and it planned hypotheses.

\subsection{Economic factors}

Level of development: GDP in line with capita is one variable which might be maximum normally used in the tax effort literature as a proxy for monetary development. It may predict a superb dating among GDP in line with capital and revenue collected because of the higher potential to pay in a society with higher income (Bahl, 1971 \& Fox and Gurley, 2005). Based on the Wagner regulation, because call for public offerings is sensitive to earnings (it is elastic), financial development is accompanied by a sped up request for public goods and services which need to be financed with the aid of growing tax revenue. Also, improvement is associated with a larger capability to levy and gain taxes (Chelliah, 1971). Hinrichs (1966) and Tanzi (1992), factor out to a high-quality hyperlink among development and tax revenues of a country. Per capita earnings have additionally been a factor in the wonderful effect on tax revenue in empirical research at the same time as not discovered to be sizeable in research, a few studies have also located it to have a bad impact (for instance, Alm and Martinez-Vazquez, 2003). Income level, measured as GDP in line with capita, a proxy for the extent of a rustic's development, and it is expected to be undoubtedly associated with the government's capacity to collect revenues and the residents' potential to pay taxes. Thus, its miles expected that GDP, consistent with capita to have a high-quality and massive effect on monetary revenue (Bahl, 1971; Fox, et al., 2005; Piancastelli, 2001; Gupta, 2007; Bird, et al., 2004 \& Le, et al., 2008).

The literature shows that economic development is an idea to bring about every advanced name for public expenditure (Tanzi, 1987) and a more taxable capability to fulfil such demands (Musgrave, 1969). Musgrave 
argues that the shortage of availability of 'tax handles' may limit tax collection at low tiers of earnings, and people's boundaries need to end up much less excessive because the economy develops. There is a huge consensus in the literature on using steady with capita profits as a proxy for the general improvement. It has a 'normative' significance from the taxation factor in view (Bahl, 1971 and Ansari, 1982). Per capita profits are an index of the excess income available for taxation because of financial development. A higher step with capita income, reflecting a higher stage of development, is held to show a higher capacity to pay taxes and a more capacity to levy and gain them (Chelliah, 1971). Therefore, from these perspectives, this variable expected to have a positive sign.

Trade liberalisation: Openness degree, that's measured as the percentage of worldwide alternate in GDP, can also have a sizable effect on tax revenue. It can be taken into consideration as an indicator of the liberalisation degree of the economic system. Certain functions of global change make it more amenable to taxation than domestic activities. In growing nations, the worldwide trade zone is the maximum monetised sector of the economic system. This import and export shares can be a vital determinant of tax revenues (Karagöz, 2013). The impact of alternate liberalisation can be ambiguous because of the opposite outcomes on taxes.

In one component, more mobility of products and factors of producing in big elements represents multiplied mobility of the tax base, and therefore, likely reduce income (Keen and Mansour, 2010). It could have a bad effect on taxes and monetary income as it predicts higher alternate openness to decrease taxes amassed on imports and export. Trade tax revenues being a primary supply of taxable income in developing countries (Rodrik, 1998; Piancastelli, 2001; Norregaard and Khan, 2007; Gupta,2007 \& Aizenman and Jin Jarak,2009). Common commentary besides the results of the sooner research shows openness to be a crucial detail affecting tax strives in growing global locations. Conversely, given that imports and exports take location at specific places commonly little information in a country; they are tremendously smooth to tax, leading to superior revenues (Alonso and Garcimartin, 2011). Trade/export/import or in the standard term openness share of GDP was discovered to have a high-quality and vast effect on the general tax proportion of GDP via much research- including Bahl (2003) and Ahsan and $\mathrm{Wu}$ (2005). Because higher alternate openness leads to higher monetary boom prices, open economies develop quicker; and as a result, they may amass greater taxes with growing this tax base. It is expected that the second one effect outweighs with Asian countries and change, openness has an effective impact on taxes and total monetary revenue. Gupta (2007) files that if this liberalisation is undertaken through a reduction in tariffs, then it's far expected that it might decrease tariff revenues. Keen and Simone (2004) argues revenue may boom if exchange liberalisation takes location through tariffs or quotas, eliminations of exemptions, discount in tariff peaks and improvement in customs manner. Rodrik (1998) also involves the end that there may be a fantastic affiliation between trade openness and the authority's consumption, as humans demand (and receive) the growing amount of public items in greater open economies challenge to external dangers. Trade taxes have traditionally been a chief supply of government sales throughout the early tiers of economic improvement because they're less difficult to gain than home profits taxes or intake taxes while tax management is rudimentary and it confines tax handles (Tanzi, 1987). The administrative ease with which they can gather alternate taxes makes them an attractive supply of government revenues while administrative competencies are scarce (Linn and Weitzel, 1990). Entrance and exit to the country take place in specified locations that facilitate tax collection. From these arguments, it has expected a sign of positive for developing countries since its administrative easiness as compared with other taxes.

Share of agriculture as a percentage of GDP: as a proxy to control for the problem with gathering taxes. In the growing international locations, it is tough to tax the agricultural quarter, considering an oversized a part of it comprises subsistence and little farmers, difficult to impose a tax at the large numbers that promote their products in casual markets (Stotsky and WoldeMariam, 1997). In line with, they have a look at of Shin (1969) and Piancastelli (2001) discovered agricultural a proportion of GDP to have a poor and significant effect on the general tax revenues proportion of GDP at the same time as Alm and Martinez-Vazquez (2003) said a bad however insignificant impact of an agricultural proportion of GDP in a panel of evolved and developing international locations. A robust poor relation among agriculture's percentage of GDP and tax sales can be expected., on account that many public zone supports are urban based a declining percentage of agriculture in GDP is related to growth in call for public prices and positioned stress to raise tax revenues (Dioda, 2012). Also, if agricultural exports have a dominant role in the exporting region of a country, it may cause a fine dating. They look at of Shin (1969) and Piancastelli (2001) discovered agricultural a proportion of GDP to have a negative and substantial effect on the total tax revenue percentage of GDP, while Alm and Martinez-Vazquez (2003) stated a negative however insignificant impact of agricultural percentage of GDP in a panel of advanced and growing nations. Therefore, this variable has an expected sign of negative.

External debt: The revenue potential is affected by the debt of a country as to generate the essential foreign exchange to carry the debt, a country may additionally reduce imports and import taxes can be decreased. Alternatively, the coverage may be to grow import tariffs or different taxes if you want to check in price range surplus to service the debt (Gupta 2007). Therefore, it's much predicted that the level of indebtedness of the country is related to the revenue potential of the countries.

The growth of public spending has generated massive economic deficits in many nations, leading to will 
increase in the share of public debt relative to GDP. The existence of a massive public debt has important implications for the taxation capability of any country. With this kind of huge debt, the government wishes to elevate the revenues important to carry it. When the interest on the debt exceeds net borrowing plus the reduction in non-interest expenditure the extent of taxation must move until the fee of the boom of the economic system is high sufficient to neutralise the boom. Therefore, public debt and authorities spending play a position in determining the extent to which countries may take a benefit in their taxable ability (Tanzi, 1987). The effect of a financial deficit and/or a public debt depends no longer handiest on its size, however additionally on how its miles financed. An increasing public debt may encourage the government to attain more revenue through, e.g., elevated import duties if revenues from that supply are regarded as extra leading to an inflation tax. A huge public debt implies the need for authorities to elevate revenue with a purpose to carry the debt, especially whilst the interest on the debt exceeds net borrowing plus the viable reduction in non-interest expenditure. Therefore, the dimensions of the public debt are the helpful determinant of the prevailing and the destiny tax degree. Also, a big public debt may sign positive political traits or weaknesses. Tanzi (1992) argues that on stability a high debt burden would elevate the tax stage, ceteris paribus. Similar consequences may arise from external debt. A distinctive debt variable relates to external debt. Tanzi (1989) has cautioned that an excessive debt burden can create macroeconomic imbalances that could have a tendency to lessen the tax level. Servicing of the foreign debt requires a trade account surplus, which might also require a reduction in imports. Therefore, this variable expected to has a negative sign.

Services organizations: Because of several factors, (fairness and political-economic system troubles), many countries exempt agriculture from taxes. A similar case can be made for several services groups. Therefore, the bigger the percentage of these sectors in GDP, the greater the difficulty it will probably be for tax administrations to accumulate revenues. Therefore, this variable expected to has a negative sign.

Construction organisations: The construction segment in most countries has a high percentage of output produced informally and consequently difficult to attain with the aid of tax administrations (Jewell et al., 2005). Therefore, this variable expected to has a negative sign.

Manufacturing organisations: these organisations are less difficult to tax than agricultural corporations in view that enterprise proprietors typically hold better books of debts and facts. Manufacturing can generate large surpluses if it is green, as a result affecting the tax effort (Teera and Hudson, 2004). Therefore, this variation expected to have a positive sign.

Official exchange rate: Tanzi (1989) put up several huge-ranging hypotheses of the connection among many macroeconomic variables, together with the alternate fee and tax revenues. He set up that there may be regularly an inverse dating among a country's tax revenue and the actual degree of its exchange rate. He argues that overvaluation has an instantaneous impact through suppressing import and export bases measured in home and foreign money phrases. This reduces collections of global exchange taxes and gross revenue and excise taxes that are normally imposed on domestic and imported intake. Overvaluation also has oblique consequences by reducing the motivation to supply goods for export, encouraging capital flight and currency substitution, weakening the balance of the bills, encouraging black markets, and inspiring alternate regulations (Agbeyegbe, et al., 2004). Because of these reasons, this variable expected to have a negative sign.

Gini coefficient: As Bird et al. (2004), Gupta (2007), Pessino and Fenochietto (2010), \& Alonso and Garcimartin (2011), argues that the earnings inequality variable is measured via the Gini coefficient, which represents the extent to which the distribution of earnings or intake inside a country deviates from the same division. They measure it that growing income inequality reduces the tax base via multiple channels. For instance, in a greater unequal society, the administration relies upon on the better profits, agencies for revenue collection, which reduces the tax base. As stated beneath Gupta (2007) look at, make use of tax shape (direct as opposed to indirect taxes) as a proxy for income distribution and argue that seeing that indirect taxes have a tendency to be regressive, they increase earnings inequality and reduce the tax base. In an equal, as Alonso and Garcimartin (2011) factor out higher profits, inequality may direct to a bigger informal region which hinders tax collection. In addition, it can make a political economy argument that income inequality also represents concentrated but effective pastimes in the society, which may not be without problems amenable to paying higher taxes. Because of these reasons, this variable expected to have a negative sign.

Broad Money/monetisation: Share of Broad Money in GDP economic system's monetisation is crucial in determining the tax potential of an economic system. An economy in this extraordinarily monetised will recognise higher tax revenues than the much less monetised. They look at therefore expects the share of large money in GDP to have a fine impact on the tax percentage. Therefore, this variable expected to have positive significance. From the above literature, it can generate the first hypothesis.

H1: Economic factors significantly affect country tax revenue potential.

\subsection{Demographic Factors}

Age dependence: Age dependency, calculated because the ratio of dependents (the people under age 15 and above 
age 65) to the running-age population (the ones, elderly 15-64), is anticipated to have a bad effect on the tax base.

The relationship between demographic change and fiscal viability has been the focus of many papers (Higgins, 1998; Nishiyama et al., 2000; Manabu et al., 2004 \& Bosworth et al., 2004). Most studies on the aging population are concerned with developing countries. Higgins (1998) performs one of the most extensive studies related to OECD countries. He suggests that the aging population influences GDP by three mechanisms. First, the decrease in workforces (productive population) increases the dependency ratio directly. Second, a higher dependency ratio in effect reduces private savings. Second, the rise of the senior population would increase government spending on retirement and health care. The increases in spending increase the budget deficit and raising the ability of public investors.

Population density: Another demographic issue is populace density, whose effect at the revenue capacity and revenue effort is ambiguous. On the only hand, better attention of human beings has to make taxation less difficult. Large populace density may also encourage casual activities difficult to tax (Mkandawire, 2010). Because human beings stay towards every other information, transactions come to be extra workable; this has a tendency to lessen revenue collection (Kau and Rubin, 1981). Population density is believed relevant, consistent with the literature, because of its effect on a few sizeable economies of scale. It is hard however to point out the path of the impact without a scientific observation. For example, on the one hand, given an excessive population density, the extent of tax exemptions may be excessive given that, in growing international locations, it takes congestion into consideration to be a trademark of backwardness (Ansari, 1982). On the opposite hand, perhaps the higher the density of the populace, the better will be the use of taxable resources and the tax authorities should intensify their efforts to gather taxes at a distinctly minimal value compared with a carefully populated country. Conversely, in a thinly populated place, administrative fees are anticipated to be higher in phrases of overall yields and much less encouraging for collection of tax revenue. Therefore, this variable expected to have a positive sign.

Education (literacy rate): Education, measured by using the UN's Education Index, has been often used as another important demographic thing of a country's revenue capability. The effect of training is likewise ambiguous. On the one hand, the more educated humans are the higher they can recognise the connection between public goods provision and the significance of paying taxes to finance them (Pessino and Fenochietto, 2012). On the alternative aspect, the extra knowledgeable humans are, the greater informed they become regarding a way to keep away from paying taxes, in which case it'll be expected a terrible effect of training on revenue collection. Therefore, this variable expected to have a positive sign.

Urbanisation: Urbanisation is vital for its political, social and cultural functions. It is expected that urbanisation and tax revenue need to exhibit a wonderful hyperlink. Since it increases citizen demand and desires for public services and products (Tanzi, 1987). The creator additionally delivered that urbanisation, which has a tendency to be connected with the improvement, brings about a greater call for public offerings whilst at the equal time facilitating tax series. The density of the population need to be without a doubt connected with tax revenue, as it ends in a reduction in the value of tax series and controlling for tax evasion (Ansari, 1982) and the government's potential to gain taxes is more suitable through structural changes, which can be related with urbanisation. Therefore, this variable expected to have a positive sign.

Population growth: The demographic variables include population growth and as the rate of population growth increases, the revenue collection system finds difficult to capture new revenue payers especially when revenue collection administration capacity is weak. Therefore, the population growth rate is expected to be negatively related to the revenue potential of a country (Javid and Arif, 2012). From the above literature, it can plan the second hypothesis.

H2: Demographic factors significantly affect country tax revenue potential.

\subsection{Policy Factors}

Inflation: the inflation charge as a macroeconomic policy variable that affects the investment and earnings level of the country. The result of inflation on the tax revenues is doubtful. Sometimes, because of the Oliveira-Tanzi impact (Oliveira, 1967; Tanzi, 1977), hyperinflation decreases the real price of tax revenues because of the lags between tax liabilities and the real collection. Also, sure forms of taxes, inclusive of excise responsibilities, which are levied at specific rates won't be well-indexed, in which case high inflation directs to a decrease in their actual value (Easterly and Schmidt-Hebbe, 1991). On the alternative hand, inflation may additionally raise revenues in innovative tax systems if it lists the tax charges with a major lag (Alonso and Garcimartin (2011). In Armenia, improvement in institutions, and policy measures designed to reduce the dimensions of the shadow economy system is critical as Pessino and Fenochietto (2010) through the usage of stochastic tax frontier evaluation finding shows that there is the poor relationship between tax revenues and inflation (CPI). Therefore, this variable expected to has a negative sign.

Foreign direct investment (FDI): Foreign direct investment (FDI) is diagnosed as one factor that help to explain versions in tax revenue. One side of the argument focuses on the elevated tax revenues expected from multiplying investments. This argument fashioned the rationale behind tax incentives and policies such as low 
statutory charges and the selective preferential tax remedy, like free zones, tax vacations, and credit is associated with tax opposition (Drummond et al., 2011). On the alternative hand, there is rising literature that shows how developing international locations are dropping tax revenues because of the exemptions. So, the impact of FDI on tax revenue is an issue of empirical supporting activities which has expected positive sign in the long run.

Official development assistance (ODA) / Foreign aid: Foreign resource inflows to developing international locations has increased sustainable inside the latest beyond to be used in financing the growing proportion of recurring fees. Although recipient countries are anticipated to supplement the inflows by using growing home tax sales, the record suggests that this has no longer been the case with most of these nations. Some theoretical and empirical proof suggests that a boom in foreign useful resource inflow might lessen effort in revenue series Mbatia (2018). The authors analysed the impact of overseas aid on tax revenue in 107 countries within the period 1970 to 2000. The paper majorly investigates the effect of grants and loans on domestic revenue mobilisation along with different structural variables. They located out that it undoubtedly relates concessional loans are undoubtedly to tax sales, while grants are negatively related. Total overseas aid changed into finding to impact home revenue mobilisation negatively. This means that the negative effect from grants outweighs the high-quality effect from loans, and consequently the overall impact becomes poor. Therefore, ODA expected to have a negative sign. From the above literature, it can produce the third hypothesis.

\section{H3: Policy factors significantly affect country tax revenue potential.}

\subsection{Institutional Factors}

Corruption Bird, Martinez-Vazquez, and Torgler (2004) conclude that the rule of regulation and control of corruption is a vital prerequisite for a greater high-quality revenue attempt. For example, terrible law and order situations in the economic system induce people to avoid tax and non-tax bills. If corruption is higher in a financial system, a huge part of the enterprise network might choose to work underground by paying bribes to head off high revenue payments. If societies have felt that their pursuits are properly represented on authorities' stage and they may be glad about the quality and quantity of public items like health, training and so forth, there would be willing to pay taxes. The preceding empirical proof suggests that a high degree of corruption reduces revenue collection. Abed and Gupta (2002) and Gupta (2008) stated that taxpayers who cope with rampant corruption are less inclined to pay taxes. Corruption, similarly, depresses overseas investment, which negatively impacts monetary pastime and the tax base. Corruption is measured with the ICRG's evaluation of corruption within the political risk component tool. Lower rankings suggest "high government officials are in all likelihood to call for unique payments" and that "illegal payments are commonly predicted throughout decrease ranges of authorities" in the form of "bribes related to import and export licenses, trade controls, tax evaluation, police protection, or loans." Lower rankings imply high authority officials are probable to demand special payments" and that unlawful bills are commonly anticipated all through decrease stages of government" within the form of bribes connected with import and export licenses, alternate controls, tax assessment, police safety, or loans (ICRG, 2018).

This is an evaluation of corruption within the political machine measured with the ICRG's evaluation. Such corruption is a danger to overseas investment for numerous motives: it distorts the monetary and economic environment; it reduces the efficiency of presidency and commercial enterprise by means of enabling humans to expect positions of strength thru patronage as opposed to capacity; and, last however not least, introduces an inherent instability into the political procedure. The maximum common form of corruption met without delay by using commercial enterprise is economic corruption in the shape of needs for special bills and bribes linked with import and export licenses, alternate controls, tax exams, police safety, or loans. Such corruption can make it hard for behavior business successfully, and in some cases may force the withdrawal or withholding of funding. Although this research degree takes such corruption into consideration, it's a far greater concern with real or capability corruption in the shape of excessive patronage, nepotism, activity reservations, 'desire-for-favors', secret celebration funding, and suspiciously near ties between politics and commercial enterprise. In this research view, these insidious types of corruption are potential of a whole lot extra danger to overseas enterprises in that they are able to cause popular discontent, unrealistic and inefficient controls of the state financial system, and inspire the development of the black market. The best threat in such corruption is that at some time it will become so overweening, or a few important scandals may be abruptly revealed, as to provoke a popular backlash, ensuing in a fall or overthrow of the authorities, a chief reorganizing or restructuring of the country's political establishments, or, at worst, a breakdown in law and order, rendering the country ungovernable (ICRG, 2018).

Many papers addressed the causes of tax inefficiency (Pitt and Lee, 1981; Battese, 1995 and Battese and Coelli, 1992). Corruption is seen as an important factor in reducing tax revenue and being able to add rents to officially pay taxes. Corruption can reduce the burden of corporate taxes (Good Speed, Martinez-Vazquez and Zhang, 2011); on the other hand, a marginal corporate tax is sometimes argued (Olken and Pande, 2011). More generally, there are two ways that corruption can vitiate efforts to increase taxes. First of all, corruption is an unregulated tax levy on tax payments that results in a higher effective tax on taxpayers than is calculated from public accounts. Attempts to increase taxes are likely to be met with more resistance and greater evasion. Second, 
the payment of corruption does not contribute to the financing of public goods and services. If higher taxes lead to higher rates of corruption, taxpayers will try to avoid it even more. Third, corruption is the result of the negotiating position given to tax collectors by tax policy decisions. Higher tax rates increase the bargaining position of tax collectors, enabling them to collect higher incomes from taxpayers.

Either corruption is only an input variable that influences potential revenue collection by reducing the tax base is not clear, or it is also the determinant of technical inefficiency. Therefore, it also includes corruption in the equation of inefficiency. By creating permanent instability in the political system, corruption will increase technical inefficiency in the tax system (Cyan et al., 2013). Therefore it is assumed a negative relationship between this variable and tax revenue potential as the variable reflects the risk of corruption, with higher values meaning lower risk. Therefore, the higher the corrupt practices in the country, the lower tax revenue potential.

Government Stability: It is an assessment of the authorities' potential to carry out its declared program (s), and its potential to live in the workplace. This is an assessment of each of the government's capability to perform its declared software(s), and its capability to live in the workplace. The danger rating assigned is the sum of three subcomponents, each with a maximum rating of 4 factors and a minimum score of zero points. A rating of four points equates to very low risk and a score of zero points to very high risk (ICRG, 2018). From the above literature, it can create the fourth hypothesis.

H4: Institutional factors significantly affect country tax revenue potential.

\section{RESEARCH METHOD AND MODELS SPECIFICATION}

In the quantitative scenario, the researcher tests a theory by specifying a narrow hypothesis and the collection of data to support or refute the hypothesis. In this scenario, to collect the data, an instrument that measures the attitudes, and the information collected is analysed using statistical procedures and hypothesis testing (Creswell, 2009). Since this study mainly focuses on quantitatively examining the interaction of variables from the extant literature, the positivists' paradigm was the suitable choice and it provided quantitative patterns. Because this paper investigates the relationships between variables by constructing research hypotheses from existing literature, it was fitting to choose a deductive method. This study covers all Sub-Saharan African countries which have 19 years secondary panel data (2000-2018) at the time of data collection on variables desire to investigate taken from IMF International Financial Statistics (IFS), World Development Indicators (WDI), and World Bank database, World economic outlook (WEO), Transparency International (TP), African Economic Outlook (AEO) and International Countries Risk Guide (ICRG). Based on the model planned, a statistical software package such as the statistical stata was used.

Subsequently updated by many writers (for example, Jondrow et al., 1982; Jha et al., 1999; Alfirman, 2003; Ndiaye and Korsu, 2011; Casteñeda and Pardinas, 2012; Fenochieto and Pessinon, 2013; IMF, 2013b; Cyan et al., 2013; Alm and Duncan, 2014; Langford and Ohlenburg, 2016 \& Garg et al., 2017) basic Model for Stochastic Frontier Analysis, as demanded by Aigner et al. (1977) and Meeusen and van den Broeck (1977). This paper adopted this model by applying it in the stochastic analysis of the tax frontier.

$$
\frac{T}{Y i t}=f(X i t ; \beta) \cdot \xi i t . \mathrm{e}^{\text {vit }}--------(1)
$$

Where

$$
\begin{aligned}
& \quad \frac{T}{\text { Yit }} \text { is the actual tax revenue to GDP ratio for country } \mathrm{i} \text { at time t. } \\
& \quad X i t \text {, is an expression given to the production function normally in economics, but this context the } \\
& \text { vector of input } X \text { are to be transformed in to tax revenues, in line with the parameter } \beta \text {, } \\
& \quad \text { Git is the tax effort for country } \mathrm{i} \text { at time t. } \\
& \text { specification. }
\end{aligned}
$$

Thus, the entire expression $\frac{T}{Y i t}=f(X i t ; \beta) . \xi i t . \mathrm{e}^{v i t}$ defines the stochastic tax frontier; specifies the tax potential of the country, $i$ at time t, and what the actual tax to GDP ratio would be if effort $\xi$ it were equal to 1 . The general model specified in equation (1) above can be further detailed as follows: the production function component of the equation (1) is assumed to take the form of Cobb-Douglas, i.e. linear in logs, as specified here below. In the definition of Qit= $\ln (\mathrm{T} /$ Yit) where $\mathrm{T}$ is taxes and $\mathrm{Y}$ is GDP output. The following new definition is given by defining $\mathrm{Xit}=\ln (\mathrm{Xit})$, as an input vector of economic, demographic, policy and institutional factors, and by defining the term ' inefficiency' Uit $=-\ln (\xi i t)$.

$$
\text { Qit }=\alpha+\beta^{\prime} X i t+v i t-u i t-------------------(2)
$$

It is possible to more specify the model in equation (2) by incorporating an observable heterogeneity, i.e. environmental variables (let it be $\boldsymbol{Z}$ ) which are observable but not captured in the model as a direct input in to tax collection, but that could influence tax potential, Tp, gives the following specification(Battese \& Coelli, 1995).

$$
\text { Qit }=\alpha+\beta^{\prime} X i t+\delta p^{\prime} Z i t, p+v i t-u i t-------------(3)
$$

Where, uit $\sim N^{+}\left(\mu \mathrm{it}, \sigma^{2} \mathrm{u}\right), \mu \mathrm{it}=\delta \mathrm{e}^{\prime}$ zit, e and vit $\sim \mathrm{N}\left(0, \sigma^{2} \mathrm{v}\right)$ 
Here the specification vit - uit is expressed as a composite error term that incorporates both the random shock vit, assumed to be normally distributed and independent of uit, the strict positive inefficiency term. The 'inefficiency' term uit is assumed to be a truncated normal distribution. This 'inefficiency' is will be defined in terms of lack of tax effort. Hence, the stochastic frontier is specified by $\alpha+\beta^{\prime} x i t+\delta p^{\prime} z i t, p+v i t$, specifies $(\log )$ tax ratio that a country $\mathrm{i}$ could achieve in time period $\mathrm{t}$, in the absence of inefficiency, i.e. uit $=$ 0 or equivalently if effort $(\xi i t)=1$. The inefficiency term uit varies across time in the country and is partly influenced by the observable factors zit, e. Finally, the distribution of the estimated stochastic frontier parameters, i.e. inefficiency (lack of effort, uit), stochastic error, vit and tax effort, ,it, all proof main specifications was checked by using their respective descriptive statistics (mean and standard deviation).

Following Battese and Coelli (1995), who introduced a panel data model with time-varying inefficiency that reflects observable heterogeneity, the parameters of the stochastic frontier and the inefficiency model are estimated simultaneously to avoid bias (Wang and Schmidt, 2002) using the maximum probability. More specifically, this study uses the empirical methodology used by in previous research of Javid and Arif (2012), Khwaja and Iyer (2014), Kumbhakar, Lien and Hardaker (2014), Brun and Diakité (2016) and Langford \& Ohlenburg (2016) with modification via along with extra tax revenue potential variables primarily based on panel data stochastic frontier analysis of truncated-normal specifications. The present study analyses tax revenue potential generated from equation (3) for Sub - Saharan African countries over 19 years duration.

$$
\begin{gathered}
\frac{T}{Y i t}=\alpha i+\beta 1 \ln E i t+\beta 2 \ln D i t+\beta 3 \ln P i t+\beta 4 \ln I Q i t+\operatorname{agland}+b \operatorname{san}+\theta \mathrm{i} \\
\text { vít }- \text { uit }----------(4)
\end{gathered}
$$

Where:

$>\ln \frac{T}{\text { Yit }}=$ is the natural logarithm of tax revenue as a percent of GDP in country $i$ at time t,

$\alpha \mathrm{i}=$ is the country $\mathrm{i}$ fixed effect,

$>\ln E i t=$ is the natural logarithm of economic variables

$>\ln \mathrm{Dit}=$ is the natural logarithm of demographic variables

$>\ln \mathrm{Pit}=$ is the natural logarithm of policy variables

$>$ lnIQit is the natural logarithm of institutional quality variables

$>\beta 1=\beta 4$ are the slope parameter estimate of economic, demographic, policy and institutional quality variables respectively

$>$ agland is agricultural land (sq. km) used as instrumental variable to solve endogeneity problem.

$>$ bsan is People using at least basic sanitation services (\% of population) used as instrumental variable to solve endogeneity problem.

$>\theta \mathrm{i}$ is the random country effect.

$>$ Vit $=$ is the country's latent heterogeneity; the random shock

uit is inefficiency' term

(Note that the detail source of data depicted on Appendix)

\section{RESULTS and DISCUSSIONS}

\subsection{ASSUMPTION TEST}

\subsubsection{Endogeneity}

As stated by Botlhole (2010) and Ali and Isse (2006), the use of instrumental variables usually minimizes the problem when an explanatory variable correlates with the error term. Two instrumental variables were applied to the model. The first is agricultural land, and the second is basic sanitation accessibility. Agricultural land area as an income instrument explained this option because large countries are often wealthy on average. Agricultural land may therefore be used to minimize the problem of endogeneity as instrumental variables. The subsistence-farm agriculture sector employs a large proportion of the population, which is over 60 percent of the total workforce, and is active in agriculture in Sub-Saharan Africa (Botlhole, 2010 and Ali and Isse, 2006). The access to improved sanitation systems that refers to the percentage of the population using enhanced sanitation facilities derived from the dataset of World Bank development indicators. The theory is that economic growth depends on efficient health human resources. Health status, as Audibert et al. (2012) said, is a major predictor of economic development. The inclusion and exclusion of these instrumental variable changes the results broadly across each model estimated (see Table3 model 2, 4, 6 and 8).

\subsubsection{Multicollinearity}

Multicollinearity, that may emerge when there appear to be an excessive correlation between two or greater explanatory variables each other. In order to check the presence of colliniarity or multicollinearity Pearson pairwise correlation test was used and to resolve this problem, highly correlated explanatory variables are used in separate species. In the current study, Table 1 Pearson pairwise correlation results show that with exception of 
corruption and government stability (96.0\%) correlation and GDP per capita and share of agriculture (69.2\%) correlation, there was no problem of multicollinearity in tax revenue potential explanatory variables. Bird et al. (2004) shows that variables with a correlation above 0.80 could certainly be troublesome and sometimes even smaller correlation levels could cause problems. To avoid the possibility of multicollinearity using highly correlated explanatory variables entered in the model step by step specification was proposed by Bird et al. (2004) and Gupta (2007). Therefore, for tax revenue potential models, to alleviate this problem each model has eight (8) iteration as follows: model 1 up to model 4 excluding share of the agricultural sector from the model and add GDP per capita and model 5 up to model 8 excluding GDP per capita and adding shares of the agricultural sector. Corruption entered in model 1, model 2, model 5 and model 6 excluding government stability and then in model 3 , model4, model 7 and model 8 excluding corruption and add government stability. The estimation results based on this iteration strategy were significantly changed.

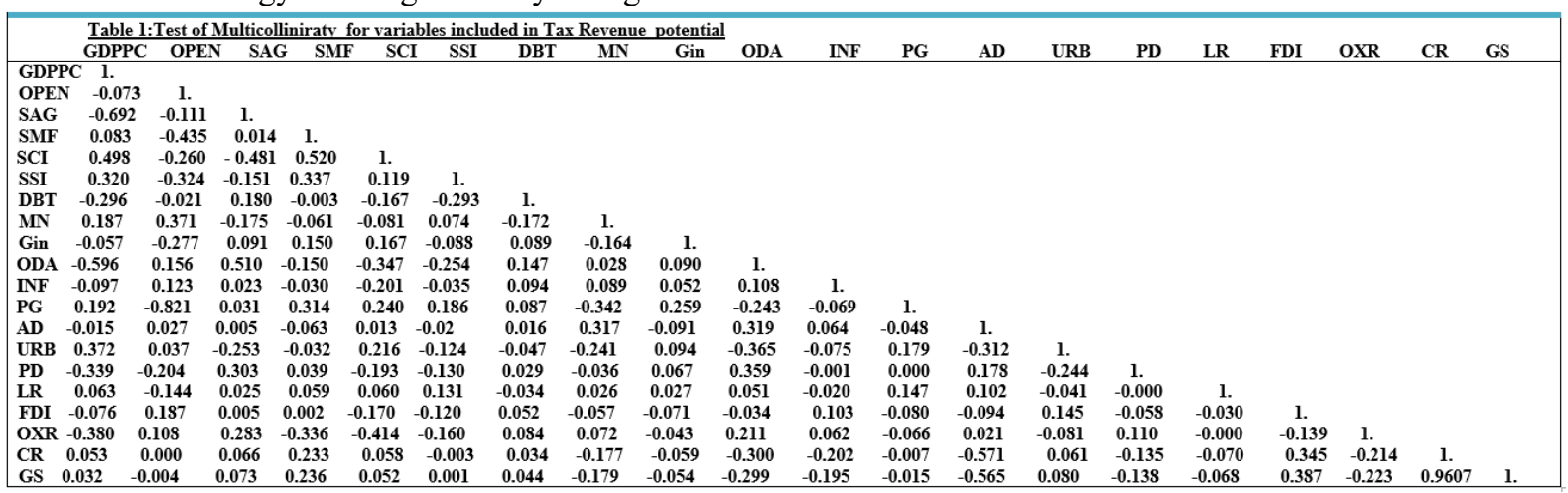

(Source: Author own computation)

\subsection{EMPIRICAL RESULTS}

Table 2 shows that the average actual tax revenue collection during the period of 2000 to 2018 for the sample of 23 sub-Saharan African countries is less than the forecast tax revenue collection. The truncated normal model analysis result indicates that on average during the study period the highest actual tax revenue collection countries from their potential as comparison are Namibia (29.05\% actual and potential $35.63 \%$ ), South Africa $(27.34 \%$ actual and $33.96 \%$ potential) and Angola (19.30\% actual and $35.04 \%$ potential), whereas the lowest one are Sierra Leone $(8.63 \%$ actual and $29.43 \%$ potential) Ethiopia( $8.40 \%$ actual and $25.50 \%$ potential) and Democratic Republic of the Congo( $6.18 \%$ actual and $27.99 \%$ potential). These shows that on average, almost all of the sampled Sub-Saharan African countries collect their taxes, which is less than what could be collected. The chi- square statistics for Wald test of the null hypothesis that all the slope coefficients are equal to zero. The value of chisquare statistics highly significant in all the specification that the overall fit of the models is quite satisfactory. 


\begin{tabular}{|llcc|}
\hline \multicolumn{3}{|l}{$\begin{array}{l}\text { Table 2: Comparison } \\
\text { model }\end{array}$} & \multicolumn{3}{l}{ Average Actual Tax Revenue and Potential Tax Revenue using Truncated normal } \\
\hline Country & Year & $\begin{array}{c}\text { Average Actual Tax Revenue } \\
\text { Ratio }\end{array}$ & $\begin{array}{c}\text { Average Potential } \\
\text { Tax Revenue }\end{array}$ \\
\hline South Africa & $2000-2018$ & 27.34 & 31.63 \\
Namibia & $2000-2018$ & 29.05 & 33.34 \\
Kenya & $2000-2018$ & 17.57 & 27.74 \\
Mozambique & $2000-2018$ & 18.11 & 28.75 \\
Angola & $2000-2018$ & 19.30 & 31.72 \\
Togo & $2000-2018$ & 17.01 & 28.33 \\
Uganda & $2000-2018$ & 15.75 & 25.98 \\
Niger & $2000-2018$ & 16.41 & 27.36 \\
Zimbabwe & $2000-2018$ & 15.77 & 28.53 \\
Ghana & $2000-2018$ & 16.16 & 29.96 \\
Malawi & $2000-2018$ & 15.13 & 28.29 \\
Cameroon & $2000-2018$ & 15.66 & 30.44 \\
Zambia & $2000-2018$ & 15.02 & 29.56 \\
Botswana & $2000-2018$ & 16.75 & 33.57 \\
Côte d'Ivoire & $2000-2018$ & 14.51 & 30.24 \\
Mali & $2000-2018$ & 13.07 & 28.16 \\
Tanzania & $2000-2018$ & 10.81 & 25.93 \\
Ethiopia & $2000-2018$ & 8.40 & 23.81 \\
Madagascar & $2000-2018$ & 9.39 & 26.29 \\
Republic of Congo & $2000-2018$ & 9.82 & 27.96 \\
The Gambia & $2000-2018$ & 9.23 & 25.78 \\
Sierra Leone & $2000-2018$ & 8.63 & 25.45 \\
Dem. Rep. Congo & $2000-2018$ & 6.18 & 26.32 \\
\hline Source: Author & & &
\end{tabular}

\section{(Source: Author own computation)}

Domestic revenue mobilization solidifies ownership over development strategy and to strengthen the bonds of accountability between governments and their citizens. The collection of tax revenues has long been regarded as a cornerstone central to every nation's growth and development. However, the collection of tax revenue in subSaharan Africa has historically been low, as governments rely heavily on foreign aid and debt financing to finance these vital public goods. The main objective of this study was a comprehensive examination of tax revenue potential and its determinants in 23 Sub- Saharan African countries using a panel data set during the time span of 2000-2018. As a consequence, the first step to understanding of public revenue systems is to define and create certain typically agreed performance measurements and benchmarks. This paper uses, among other things truncated-normal specifications to estimate the tax revenue potential as well as the determinants thereof. This type of analysis helps to measure tax potential more empirically-and potentially more policy-relevant. Then it can be used to generate a stochastic tax frontier that defines a maximum estimated potential tax to GDP ratio for a certain number of determinants of inputs and environmental factors. This provides an additional dimension for policy discussions by identifying determinant factors.

The estimation results shown in Table 3 reveal that from economic factors the potential for tax revenue is positively and significantly linked to per capita GDP, trade openness, the share of the agricultural sector, the share of the service sector, the share of the manufacturing sector and monetization whereas it has a negative and significant relationship with income inequality (Gini coefficient), the share of the construction sector and official exchange rates. The tax revenue potential is positively and significantly linked to population growth and urbanization from demographic factors, and it has a negative and significant relationship with age dependency and population density. With respect to policy factors: foreign direct investment, official development assistance and inflation have a significant and negative effect on the potential for tax revenue. The results for all institutional variables are not statistically significant. This result is consistent with other studies that found that the ability to collect and pay tax increases with the level of development (see, for example, Chelliah, 1971; Bahl, 1971; Piancastelli, 2001; Bird, et al., 2004; Fox, et al., 2005; Gupta, 2007; Le, et al., 2008; Cyan et al., 2013; Fenochietto and Pessino, 2013; Garg et al., 2014; Langford and Ohlenburg, 2016; Ahmad, 2010; Chaudhry and Munir, 2010; Gupta, 2007; Javid and Arif, 2012; Gupta et al.,2004; Alonso and Garcimartin, 2011; Karagöz, 2013; Rodrik, 1998; Norregaard and Khan, 2007; Aizenman and Jin Jarak, 2009). 
Table 3: Determinants of Tax Revenue Potential under Stochastic Frontier Truncated- Normal Model

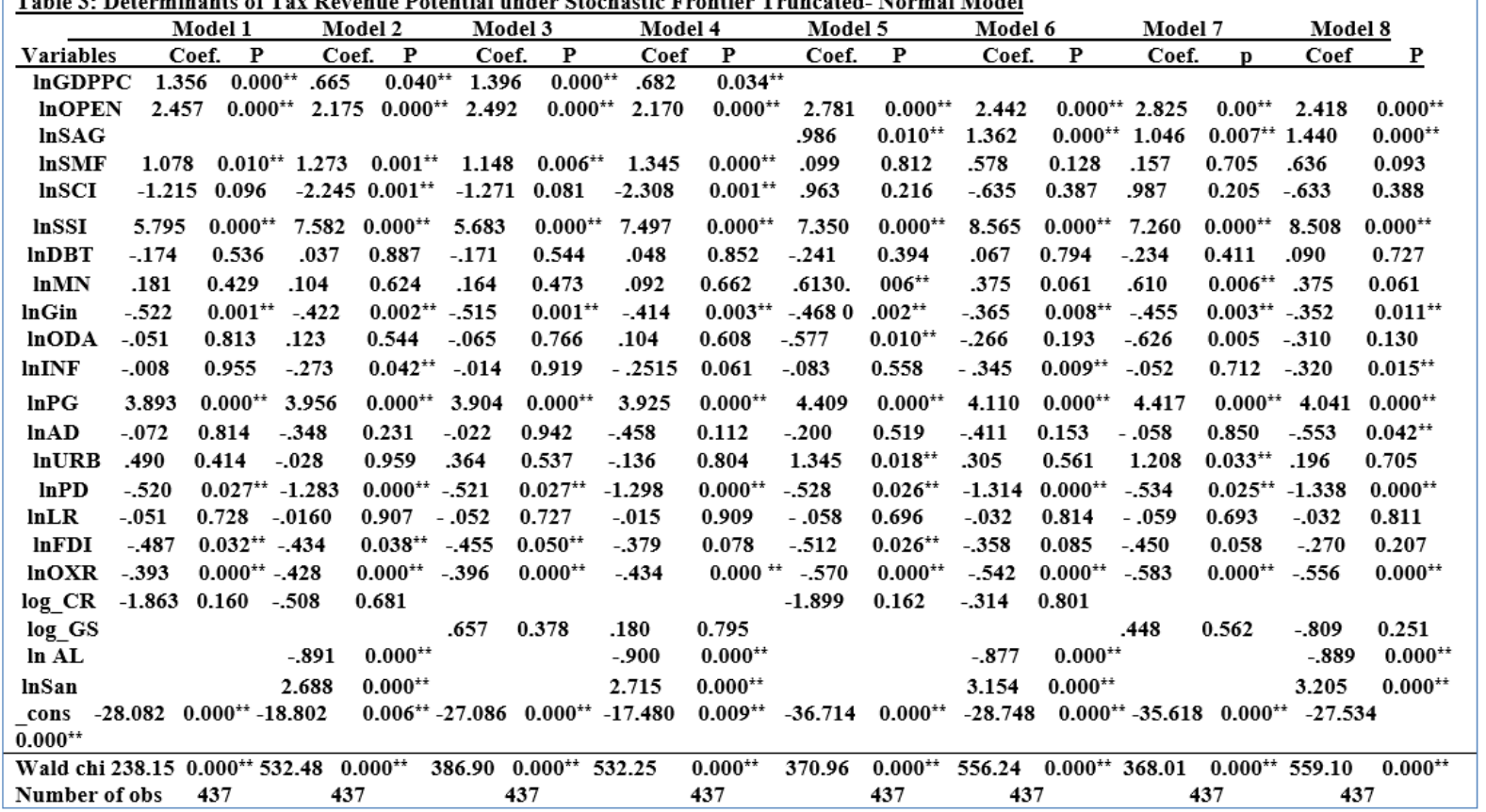

* significant at $5 \%$ confidence level

(Source: Author own computation)

\section{CONCLUSTION AND RECOMMENDATION}

\subsection{CONCLUSION}

Domestic revenue mobilisation solidifies ownership over development strategy and to strengthen the bonds of accountability between governments and their citizens. The collection of tax revenues has it has regarded long as a cornerstone central to every nation's growth and development. However, the collection of tax revenue in subSaharan Africa has historically been low, as governments rely heavily on foreign aid and debt financing to finance these vital public goods. The main aim of this study was a comprehensive examination of tax revenue potential and its determinants in 23 Sub- Saharan African countries using a panel data set during the time span of 20002018. As a result, the first step to understanding of public revenue systems is to define and create certain typically agreed performance measurements and benchmarks. This paper uses random effect estimates, fixed effect estimates, half-normal specifications, exponential and normal specifications, and truncated-normal specifications to determine the tax revenue potential and the determinants thereof. This analysis helps to measure tax potential more empirically-and potentially more policy-relevant. Then it can generate a stochastic tax frontier that defines a maximum estimated potential tax to GDP ratio for a certain number of determinants of inputs and environmental factors. This provides an additional dimension for policy discussions by identifying determinant factors. The measure of the tax revenue potential provided by either method does not provide a concrete income potential directly applicable to a country. The level of development to be sustained or achieved in either case has a weakness; tax gaps don't correspond closely to the revenue requirements.

The estimation results from economic factors shows that the potential for tax revenue has a significant positive relationship to per capita GDP, trade openness, the share of the agricultural sector, the share of the service sector, the share of the manufacturing sector, external debt and monetisation whereas it has a negative and significant relationship with income inequality (Gini coefficient), the share of the construction sector and official exchange rates. The tax revenue potential is positive and significant correlation to population growth and urbanisation from demographic factors, and it has a negative and significant relationship with age dependency and population density. Regarding policy factors: foreign direct investment, official development assistance and inflation have a significant and negative effect on the potential for tax revenue. The results are mixed for institutional variables. That is government stability has a significant and positive effect on tax revenue potential, whereas corruption has a negative and significant effect.

Based on the results, this paper concluded that both supply-side and demand-side factors are relevant to determine countries ' tax revenue potential. Therefore, a major effort remains to calculate the tax potential accurately and to stimulate discussion on the scope of tax reform for fiscal policy purposes. Hence, tax collections are identified fairly accurately in such efforts. Even though, practical estimation of the tax potential is a difficult task, but it is still important to recognize any country's potential tax gap. In a country, this is an easily visible 
option at the level of the public goods and services required.

\subsection{RECOMMENDATION}

This study suggests the empirical result that Sub-Saharan African countries have limits on extending the tax scope efficiently and reasonably, which in turn depends on the underlying taxable capacity and the initial tax collection level of the country. Although taxation is the most effective alternative to long-term funding of public spending, sub-Saharan African countries typically experience a persistent gap between the amount of actual tax revenue and their potential. Structural tax issues indicate that all countries need to adopt a long-term vision for tax reforms, and specific reform strategies cannot be "one-size-fits-all." Therefore, it is recommended that, countries with low levels of actual collection, for example, can have ample scope to increase revenues to reach their potential without aggravating economic distortions in the medium term. On the contrary, a low-income countries, placed in the situation of the relatively low collection have restricted short-term potential to increase revenue without causing high collection costs (both enforcement and administration) and creating negative opportunities for the formal sector.

\subsection{FURTHER IMPLICATION}

In the case of income reform, tax policies are of fundamental importance in all countries at vastly different levels of growth in addition to the structural factors. Furthermore, both the large-scale tax effects as well as the common pool nature of tax revenues make it difficult, in view of the resistance of the élites, to reach cooperative solutions. It is political, and hence practically challenging, to make fundamental changes to an established tax structure. Hence, the success of any tax revenue reform is highly dependent, inter alia, on the top political commitments specially to improve tax revenue inefficiency. The fundamental change to an established tax structure is politically and therefore practically challenging. The debate on revenue reforms must be country-specific and based on a political willingness and comprehensive analysis of the country's tax revenue potential, effort and inefficiency to address difficult reform steps. Hence, in general, this study recommended that before implementing a new tax revenue policy, the concerned body of any country should first determine their tax revenue potential and their determinants accordingly. The results of the study are expected to contribute insights for an empirical model of a comprehensive examination of the determinants of tax revenue its determinants in Sub- Saharan African countries. For the sake of a comparative evaluation of a cross-countries or a single country of potential tax revenues, further research work could be carried out.

\section{Reference}

Abed, G.T., and Gupta, S. eds. 2002. Governance, Corruption, Economic Performance. Washington D.C: International Monetary Fund.

AEO 2013. Financial Flows and Tax Receipts [Online]. Available:http:// www.africaneconomicoutlook.org/en/outlook/

AfDB. 2010. Domestic Resource Mobilization for Poverty Reduction in East Africa: Lessons for Tax Policy and Administration. Tunis: The Knowledge and Information Centre, African Development Bank.

Ahsan, S. M., \& Wu, S. 2005. Tax Structure and Reform in China, 1979-2002. Mimeo, Department of Economics, Concordia University, Canada.

Aigner, D. J., Lovell, Knox, C.A. and Schmidt, P. 1977."Formulation and Estimation of Stochastic Frontier Production Function Models", Journal of Econometrics, 6, pp. 21-37.

Alfirman, L. 2003. Estimating Stochastic Frontier Tax Potential: Can Indonesian Local Governments Increase Tax Revenues under Decentralization?" University of Colorado at Boulder Working Paper No. 03-19.

Ali, A. M., \& Isse, H. S. 2006. An empirical analysis of the determinants of foreign aid: a panel approach. International Advances in Economic Research, 12(2), 241-250.

Alm, J., \& Martinez-Vazquez, J. 2003. Institutions, paradigms, and tax evasion in developing and transition countries.

Alm, J., \& Duncan, D. 2014. Estimating tax agency efficiency. Public Budgeting \& Finance, 34(3), 92-110.

Alm, J., \& Martinez-Vazquez, J. 2003. Institutions, paradigms, and tax evasion in developing and transition countries.

Ansari, M. M. 1982. Determinants of tax ratio: a cross-country analysis. Economic and Political weekly, $1035-$ 1042.

Audibert M., Combes P.M., Drabo A., 2012. "Global burden of disease and economic growth." 2012.12. halshs00678713

Bahl RW. 1971. A regression approach to tax effort and tax ratio analysis. IMF Staff Papers 18:570-612.

Battese, G. E. 1995. A Model for Technical Inefficiency Effects in a Stochastic Frontier Production Function for Panel Data, 325-332.

Bird, Richard M., Jorge Martinez-Vazquez, and Benno Torgler 200). Societal Institutions and Tax Efforts in 
Developing Countries. Andrew Young School of Policy Studies, Georgia State University: Georgia, Atlanta. (Working Paper 04-06).

Bird, Richard 2010. "Taxation and Development." Economic Premise, (34), 1-5

Blundell, R., \& Bond, S. 1998. Initial conditions and moment restrictions in dynamic panel data models. Journal of econometrics, 87(1), 115-143.

Bosworth, B., Bryant, R., \& Burtless, G. 2004. The impact of aging on financial markets and the economy: A survey. Available at SSRN 1147668.

Botlhole, T. D. 2010. Tax effort and the determinants of tax ratio in Sub-Sahara Africa. In International Conference on Applied Economics-ICOAE.

Brun, J. F., \& Diakite, M. 2016. Tax potential and tax effort: An empirical estimation for non-resource tax revenue and VAT's revenue.

Castaneda, L., \& Pardinas, J. 2012. Sub-national revenue mobilization in Mexico.

Creswell, J. W. 2009. Research Design - Qualitative, Quantitative, and mixed Approaches. Research Design Qualitative Quantitative and Mixed Methods Approaches. https://doi.org/10.1016/j.math.2010.09.003

Culpeper, R., \& Bhushan, A. 2010. Why enhance domestic resource mobilisation in Africa?. Trade Negotiations Insights, 9(6), 5-7.

Cyan, M., Martinez-Vazquez, J., \& Vulovic, V. 2013. Measuring tax effort: Does the estimation approach matter and should effort be linked to expenditure goals?. International Center for Public Policy Working Paper 1308 April 2013.

Davoodi, H. R., \& Grigorian, D. A. 2007. Tax Potential vs. Tax Effort: A Cross-Country Analysis of Armenia's Stubbornly Low Tax Collection.

Dioda, L. 2012. "Structural Determinants of Tax Revenue in Latin America and the Caribbean, 1990-2009," Commission Económica para América Latina y el Caribe (CEPAL), No. 041.

Drummond, P., W. Daal, N. Srivastava and L.E. Oliveira 2012. "Mobilizing Revenue in Sub-Saharan Africa: Empirical Norms and Key Determinants", IMF Working Paper WP/12/108.

Easterly, William and Klaus Schmidt-Hebbe 1991. "The Macroeconomics of Public Sector Deficits: A Synthesis, Policy, Research and External Affairs.," The World Bank.

Ebel, R. D., Taliercio, R. 2005. Subnational Tax Policy and Administration in Developing Economies. Tax Notes International, March, 919-936.

Eltony, M. N. 2002. Measuring tax effort in Arab countries. Economic Research Forum for Arab countries, Iran and Turkey.

EU 2015. Assessing Progress in Africa toward the Millennium Development Goals, MDG Report 2015: United Nations Economic Commission for Africa, African Union, African Development Bank and United Nations Development Programme.

Garg, S., Goyal, A., \& Pal, R. 2017. Why tax effort falls short of tax capacity in Indian states: A Stochastic Frontier Approach. Public Finance Review, 45(2), 232-259.

Ghura, Dhaneshwar 1998. Tax Revenue in Sub Saharan Policies and Corruption. International Monetary Working Paper 98/135).

Gupta, Abhijit Sen 2007. Determinants of Tax Countries. (IMF Working Paper, No: WP/07/184).

Gupta, R. 2008. Tax evasion and financial repression. Journal of Economics and Business, 60(6), 517-535.

Hinrichs, H.H. 1966. A General Theory of Tax Structure: Change During Development. Cambridge, MA: Harvard Law School International Program.

ICRG 2018. "International Country Risk Guide Index." The PRS Group: New York.

IMF (2018). Domestic revenue mobilization and private investment, Sab-Saharan Africa regional economic outlook.

International Monetary Fund 2018b. "Regional Economic Outlook: sub-Saharan Africa." Washington, DC.

Javid, A. Y., \& Arif, U. 2012. Analysis of revenue potential and revenue effort in developing Asian countries. The Pakistan Development Review, 365-379.

Jewell, Carol; Roger Flanagan and Keith Cattell 2005. "The Effects of the Informal Sector on Construction," I. D. Tommelein, Construction Research Congress 2005: Broadening Perspectives. American Society of Civil Engineers.

Jha, S. 1999. Tax Evasion, Amnesty Schemes, and Black Income: Theory, Evidence, and Issues. India Development Report, 2000, 165-76.

Jondrow, J., Lovell, C. K., Materov, I. S., \& Schmidt, P. 1982. On the estimation of technical inefficiency in the stochastic frontier production function model. Journal of econometrics, 19(2-3), 233-238.

Kau, J. B., \& Rubin, P. H. 1981. The size of government. Public Choice, 37(2), 261-274.

Khwaja, Munawer Sultan Iyer, Indira (2014). Revenue potential, tax space, and tax gap: a comparative analysis. World Bank Policy Research Working Paper. 
Kumbhakar, S. C., Lien, G., \& Hardaker, J. B. 2014. Technical efficiency in competing panel data models: a study of Norwegian grain farming. Journal of Productivity Analysis, 41(2), 321-337.

Langford, B., \& Ohlenburg, T. 2016. Tax revenue potential and effort: An empirical investigation. International Growth Center (IGC) pp, 1-30.

Leuthold, J. H. 1991. Tax shares in developing economies a panel study. Journal of development Economics, 35(1), 173-185.

Linn FJ, Weitzel D. 1990. Public finance, trade and development: what have we learned? In Fiscal Policy in Open Developing Economies, Tanzi V (ed.). International Monetary Fund: Washington; 9-28.

Lotz, Joergen R. and Elliott R. Morss 1970. "A Theory of Tax Level Determinants for Developing Countries." Economic Development \& Cultural Change, 18(3), 328.

Manabu, Shimasaw. A., \& Hidetoshi, Hosoyam. A. 2004. Economic implications of an aging population: The case of five Asian economies (No. 117). Economic and Social Research Institute (ESRI).

Martinez-Vazquez, Jorge McLure, Charles Vaillancourt, Francois 2006. Revenues and expenditures in an intergovernmental framework. Perspectives on fiscal federalism, World Bank Publications.

Mbatia, C. N. 2018. Effect of foreign aid dependency on taxation revenue in Sub-Saharan Africa (Doctoral dissertation, University of Cape Town).

Meeusen, W., \& van Den Broeck, J. 1977. Efficiency estimation from Cobb-Douglas production functions with composed error. International economic review, 435-444.

Mikesell, John L 2002. Tax expenditure budgets, budget policy, and tax policy: Confusion in the states. Public Budgeting \& Finance, Vol. 22, pp. 34-51. Wiley Online Library .

Mikesell, John 2007. Changing state fiscal capacity and tax effort in an era of devolving government, 19812003 .Publius: The Journal of Federalism ,vol.37,pp. 532-550.

Mkandawire, T. 2010. On tax efforts and colonial heritage in Africa. The Journal of Development Studies, 46(10), $1647-1669$.

Musgrave RA. 1969.Fiscal Systems. Yale University Press: London, UK.

Ndiaye M.B.O., Korsu R.D. 2014. Tax Effort in ECOWAS Countries. In: Seck D. (eds) Regional Economic Integration in West Africa. Advances in African Economic, Social and Political Development. Springer, Cham.

Nishiyama, T., Matsukawa, T., \& Hanaoka, K. 2000. Is protease inhibitor a choice for the treatment of pre-or mild disseminated intravascular coagulation?Critical Care Medicine, 28(5), 1419-1422.

Oates, W.E. 1998. Comments on Fostering Fiscally Responsive and Accountable Governance: Lessons from Decentralization by Shah (pp. 97-101), in R. Picciotto \& Wiesner E. (eds) Evaluation and Development. The Institutional Dimension (New Brunswick/London: Transaction Publishers.

Olivera, Julio G. H. 1967. "Money, Prices and Fiscal Lags: A Note on the Dynamics of Inflation." Quarterly RevieBanca Nazionale del Lavoro, 20, 258-67.

Olowu, D. and Wunsch, J.S. (eds) 2004. Local Governance in Africa: The Challenges of Democratic Decentralization, London and Boulder: Lynne Rienner.

Pessino C. and Fenochietto R., 2013. "Understanding Countries' Tax Effort", IMF Working Paper 13/244 (Washington: International Monetary Fund).

Runde, D. F., Savoy, C. M., \& Rice, C. F. 2016. Global Infrastructure Development: A Strategic Approach to US Leadership. Center for Strategic and International Studies.

Shah, Anwar 1999. Fiscal federalism and macroeconomic governance: For better or for worse?

Shah, J., Higgins, T., \& Friedman, R. S. 1998. Performance incentives and means: how regulatory focus influences goal attainment. Journal of personality and social psychology, 74(2), 285.

Sheikh, M. R., Akhtar, M. H., Abbasi, M. N., \& Subhania, F. 2018. Economic Determinants of Tax Buoyancy in Pakistan: An ARDL Bounds Testing Approach. Review of Economics and Development Studies, 4(1), 1122.

Shin, K. 1969. International difference in tax ratio. The Review of Economics and Statistics, 213-220.

Smoke, P. (ed.) 2003. 'Decentralization and Local Governance in Africa', Public Administration and Development 23.1.

Stotsky, Janet G and Asegedech WoldeMariam 1997. "Tax Effort in Sub Saharan Africa.," International Monetary Fund.

Tanzi, Vito. 1977. "Inflation, Lags in Collection, and the Real Value of Tax Revenue." Staff Papers - International Monetary Fund, 24(1), 154-67.

Tanzi V. 1987. Quantitative characteristics of the tax systems of developing countries. In The Theory of Taxation for Developing Countries, Newbery D, Stern N (eds). Oxford University Press: New York; 205-241.

Tanzi 1992. "Structural Factors and Tax Revenue in Developing Countries: A Decade of Evidence." I. Goldin and L. A. Winters, Open Economies: Structural Adjustment and Agriculture. Cambridge: Cambridge University 
Press, 267-81.

Tanzi, V., \& Davoodi, H. 1998. Corruption, public investment, and growth. In The welfare state, public investment, and growth (pp. 41-60). Springer, Tokyo.

Teera, Joweria M Hudson, John 2004. Tax performance: a comparative study. Journal of international development. Vol6, pp. 785-802.

Wang, H. J., \& Schmidt, P. 2002. One-step and two-step estimation of the effects of exogenous variables on technical efficiency levels. journal of Productivity Analysis, 18(2), 129-144.

\begin{tabular}{|c|c|c|c|c|}
\hline \multicolumn{5}{|c|}{ Appendix :Variable descriptions and sources } \\
\hline Variable & Symbol & $\begin{array}{l}\text { Expected } \\
\text { sign }\end{array}$ & Description & Source \\
\hline \multicolumn{5}{|l|}{$\begin{array}{l}\text { Dependent } \\
\text { Variable }\end{array}$} \\
\hline $\begin{array}{l}\text { Tax Revenue to } \\
\text { GDO ratio }\end{array}$ & TR & & 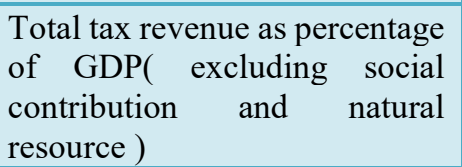 & development \\
\hline \multicolumn{5}{|l|}{$\frac{\text { Independent }}{\text { Variables }}$} \\
\hline \multicolumn{5}{|l|}{ Economic variables } \\
\hline $\begin{array}{l}\text { GDP Per capita } \\
\text { (development level) }\end{array}$ & GDPPC & + & $\begin{array}{l}\text { Real Gross Domestic product } \\
\text { divided by total population }\end{array}$ & development \\
\hline $\begin{array}{l}\text { Openness/trade } \\
\text { liberalization }\end{array}$ & OPEN & + & $\begin{array}{l}\text { Calculated as export }+ \text { import } \\
\text { divided by GDP }\end{array}$ & $\begin{array}{l}\text { IMF International Financial } \\
\text { Statistics }\end{array}$ \\
\hline $\begin{array}{l}\text { Share of } \\
\text { Agriculture }\end{array}$ & SAG & - & $\begin{array}{l}\text { Calculated as Agricultural } \\
\text { value added divided by GDP }\end{array}$ & $\begin{array}{l}\text { World development } \\
\text { indicators }\end{array}$ \\
\hline $\begin{array}{l}\text { Share of } \\
\text { Manufacturing } \\
\text { industry }\end{array}$ & SMF & + & $\begin{array}{l}\text { Calculated as manufacturing } \\
\text { industry } \\
\text { value added divided by GDP }\end{array}$ & development \\
\hline $\begin{array}{l}\text { Share of } \\
\text { Service industry }\end{array}$ & SSI & + & $\begin{array}{l}\text { Calculated as } \\
\text { industry } \\
\quad \text { value } \\
\text { GDP }\end{array}$ & development \\
\hline Monetization & $\mathrm{MN}$ & + & $\begin{array}{l}\text { Calculated as the ratio of } \\
\text { broad money to GDP }\end{array}$ & development \\
\hline Gini index & Gin & - & $\begin{array}{l}\text { Gini index measures the extent } \\
\text { to which the distribution of } \\
\text { income or consumption } \\
\text { expenditure amongst } \\
\text { individuals or households } \\
\text { within an economy deviates } \\
\text { from a perfectly equal } \\
\text { distribution. A Gini index of } 0 \\
\text { represents perfect equality, } \\
\text { while an index of } 100 \text { implies } \\
\text { perfect inequality. }\end{array}$ & development \\
\hline $\begin{array}{l}\text { Share of construction } \\
\text { industry }\end{array}$ & SCI & - & $\begin{array}{l}\text { construction } \\
\text { share to GDP }\end{array}$ & development \\
\hline $\begin{array}{l}\text { Official exchange } \\
\text { rate }\end{array}$ & OXR & - & $\begin{array}{l}\text { Official exchange rate (LCU } \\
\text { per US\$, period average) }\end{array}$ & $\begin{array}{l}\text { World development } \\
\text { indicators }\end{array}$ \\
\hline External debt & DBT & - & $\begin{array}{l}\text { External debt, total debt } \\
\text { service, interest percent of GDP }\end{array}$ & $\begin{array}{ll}\text { International } & \text { Monetary } \\
\text { Fund, World } & \text { Economic } \\
\text { Outlook Database and } \\
\text { African } \\
\text { outlook(AEO) }\end{array}$ \\
\hline
\end{tabular}




\begin{tabular}{|c|c|c|c|c|}
\hline \multicolumn{5}{|c|}{ Appendix :Variable descriptions and sources } \\
\hline Variable & Symbol & $\begin{array}{l}\text { Expected } \\
\text { sign }\end{array}$ & Description & Source \\
\hline \multicolumn{5}{|l|}{$\begin{array}{l}\text { Demographic } \\
\text { variables }\end{array}$} \\
\hline Age dependency & $\mathrm{AD}$ & - & $\begin{array}{l}\text { Age dependency ratio is the } \\
\text { ratio of dependents--people } \\
\text { younger than } 15 \text { or older than } \\
64 \text {--to the working-age } \\
\text { population--those ages } 15-64 \text {. }\end{array}$ & Development \\
\hline Population density & PD & - & $\begin{array}{l}\text { Population density (people per } \\
\text { sq. km of land area) }\end{array}$ & $\begin{array}{l}\text { World } \\
\text { Indicators }\end{array}$ \\
\hline Urbanization & URB & + & $\begin{array}{l}\text { Calculated as total urban } \\
\text { population divided by total } \\
\text { population }\end{array}$ & $\begin{array}{l}\text { World } \\
\text { indicators }\end{array}$ \\
\hline Population growth & PG & - & Population growth (annual \%) & $\begin{array}{l}\text { World development } \\
\text { indicators }\end{array}$ \\
\hline Literacy Rate & LR & + & $\begin{array}{l}\text { Calculated as } 100 \text { minus } \\
\text { illiteracy rate }\end{array}$ & $\begin{array}{l}\text { World development } \\
\text { indicators }\end{array}$ \\
\hline \multicolumn{5}{|l|}{ Policy variables } \\
\hline $\begin{array}{l}\text { Foreign } \\
\text { investment }\end{array}$ & FDI & + & $\begin{array}{l}\text { Foreign direct investment, net } \\
\text { inflows ( } \% \text { of GDP) }\end{array}$ & $\begin{array}{l}\text { International Monetary } \\
\text { Fund, International Financial } \\
\text { Statistics }\end{array}$ \\
\hline Inflation Rate & INF & - & $\begin{array}{l}\text { Calculated as the percentage } \\
\text { change in consumer price } \\
\text { index }\end{array}$ & $\begin{array}{l}\text { World development } \\
\text { indicators }\end{array}$ \\
\hline $\begin{array}{l}\text { Official development } \\
\text { assistance }\end{array}$ & ODA & - & Net ODA received (\% of GDP) & $\begin{array}{l}\text { World development } \\
\text { indicators }\end{array}$ \\
\hline \multicolumn{5}{|l|}{$\begin{array}{l}\text { Institutional } \\
\text { Quality } \\
\text { variables(IQ) }\end{array}$} \\
\hline Corruption & $\mathrm{CR}$ & - & Corruption Perceptions Index & Transparency International \\
\hline Government stability & GS & + & $\begin{array}{l}\text { Measured by item scores } \\
\text { extract from International } \\
\text { Country Risk Guide } \\
\text { political risk component. }\end{array}$ & $\begin{array}{l}\text { International Country } \\
\text { Guide political } \\
\text { component. }\end{array}$ \\
\hline \multicolumn{5}{|l|}{$\begin{array}{l}\text { Instrumental } \\
\text { variables }\end{array}$} \\
\hline $\begin{array}{l}\text { Agricultural } \\
\text { land }\end{array}$ & AL & & Agricultural land (sq. km) & development \\
\hline $\begin{array}{l}\text { Basic } \\
\text { sanitation }\end{array}$ & San & & $\begin{array}{l}\text { People using at least basic } \\
\text { sanitation services }(\% \text { of } \\
\text { population })\end{array}$ & development \\
\hline
\end{tabular}

(Source :author own formulation) 